\title{
Characterization of Probiotic Bacteria from Fermented Fruit Mix
}

\author{
S. Uma Maheshwari ${ }^{*}$, S. Amutha ${ }^{1}$, G. Hemalatha ${ }^{1}$, N. Senthil ${ }^{2}$, \\ R. Anandham ${ }^{2}$ and K. Kumutha ${ }^{2}$ \\ ${ }^{1}$ Home Science College and Research Institute, Tamil Nadu Agricultural University, \\ Tamil Nadu - 625 104, India \\ ${ }^{2}$ Agriculture College and Research Institute, Tamil Nadu Agricultural University, \\ Tamil Nadu - 625 104, India \\ *Corresponding author
}

\section{A B S T R A C T}

\section{Keywords}

Cultivable diversity, Lactic Acid Bacteria, Panchamirtham,

Fermented fruit mix

Article Info

Accepted:

20 January 2018

Available Online:

10 February 2018
Panchamirtham is a kind of fruit based fermented product with a strong flavour. Panchamirtham is made from the five types of foods were used in Hindu worship and pooja to divinity. The current study was conducted to investigate the diversity of native lactic acid bacteria (LAB) populations and characterization in the indigenous fermented fruit mix. Initially, seven hundred and eighty seven isolates were enumerated from fermented fruit mix from five different media such as Eosin Methylene Blue, Lysogeny agar, Nutrient Agar, R2A and Endo Agar. Among the 787 isolates, eighty four bacterial isolates were selected based on their colour, shape and size. A total of seven isolates were found to be acid producing based on reaction of colour changes. This research gives an extensive LAB diversity associated with fermented fruit mix and demonstrated that the influence of type of raw material and/or production location and conditions.

\section{Introduction}

Panchamirtham, which is made from hill bananas, has been one of the main dietary fibre with folate sources since ancient times. Indians prepared various traditional products which are used in Hindu worship. Panchamirtham is a traditional fruit mixture contains five types of foods.

Hence, it is a well-known and popular traditional fermented South Indian ethinic food. The manufacturing processes of panchamirtham vary from region to region.
Panchamirtham, is not only delicious and also nourshing food with medicinal value. Fermentation, a convenient method of improving flavour, increasing the added value of the products, and extending the shelf-life of foods, has been used for thousands of years. With fermentation, the nutritive quality and organoleptic attributes of foods also increase.

The consumption of fermented foods has been growing, and interests in developing new probiotics, enhancing the sensory properties of foods and adding health benefits are increasing. The probiotic properties of 
fermented foods are mainly attributed to the presence of lactic acid bacteria (LAB) (Huang et al., 2011). World widely, variety of traditional fermented foods and beverages are prepared and consumed. Fermented products are associated with desired and edible microbes which are beneficial for health. To deliver the health benefits to the consumer, it is utmost important to maintain viable probiotic cells in a product until consumption, at the minimum level usually ranged from $10^{-6}$ to $10^{-9} \mathrm{cfu} \mathrm{mL}^{-1}$ (Schoina et al., 2014), to survive the acidic conditions of the upper gastrointestinal (GI) tract and proliferate in the intestine. To enhance probiotic cell viability, several methods have been proposed, such as use of an appropriate administration matrix and microencapsulation techniques (Bosnea et al., 2017 and Gagne-Bourque et al., 2016), cell immobilization (Terpou et al., 2017), addition of prebiotics, and use of mixed starters (Yeung and Tong, 2011). Research in the field of exploring an interesting strain with probiotic potential from fermented food products as a source of new isolates are blooming.

In Asia, an array of fermented foods and beverages are produced. The people of the Himalayan region of India particularly Ladakh region consume a variety of indigenous fermented foods such as tagi khambir/skyurchuk (brown sourdough bread), zho (curd), tara (buttermilk), labo (cottage cheese), chhurphe (dried cottage cheese), (Angchok et al., 2009) and fermented vegetables and alcoholic beverages like chhang and aarak (Angmo and Bhalla, 2014). However, no work has been carried out to explore the microflora of panchamitham fermented foods of Southern India. Therefore, present study aimed on cultivable microbial diversity of lactic acid bacteria from traditional fermented foods of panchamitham at different location and widely used in screening and selection of probiotic bacteria.

\section{Materials and Methods}

\section{Sample Collection}

Samples were collected from three different locations such as Thiruparankundram, Tiruchendur and Pazhani.

Enumeration of total LAB and their isolation from panchamirtham

Ten grams of Panchamirtham sample was aseptically transferred into a $250 \mathrm{~mL}$ flask containing $90 \mathrm{~mL}$ sterile water and the contents were mixed thoroughly for $30 \mathrm{~min}$ at $150 \mathrm{rpm}$. Serial dilutions $\left(10^{-1}\right.$ to $\left.10^{-6}\right)$ were made for each sample and $100 \mu \mathrm{L}$ of each dilution was spread onto each media Eosin Methylene Blue, Lysogeny agar, Nutrient Agar, R2A and Endo agar. Bacterial colonies were incubated at $30^{\circ} \mathrm{C}$ and their counts were observed for three days continuously.

\section{Isolation and purification}

Bacterial colonies were selected based on their colour, shape and size and purified by four streak method to get a pure single colony. Purified cultures were stored in $50 \%$ glycerol in deep freezer at $-20^{\circ} \mathrm{C}$.

\section{Biochemical characterization of bacteria}

\section{Growth at different $\mathbf{p H}$ and sucrose tolerance}

The ability of the Panchamirtham to compete with the natural microbiota of the raw material and to undertake the metabolic activities expected is conditioned by its growth rate and survival in the conditions prevailing in the fermented product, i.e., an anaerobic atmosphere, rather low to high sugar concentrations and $\mathrm{pH}$. Purified isolates were tested for growth at different intestinal $\mathrm{pH}$ of 3.0, 4.0, 5.0 and 8.0. 
Fig.1 pH tolerance of lactic acid bacteria

Fig.2 Tolerance of lactic acid bacteria for different sucrose concentration

Table.1a Main characteristics of analyzed panchamirtham samples

\begin{tabular}{|l|l|l|l|l|}
\hline S. No & Samples & Location & CFU/g & No. of Bacterial Isolates \\
\hline $\mathbf{1}$ & Panchamirtham & Thiruparankundram & $3.33 \times 10^{8}$ & 334 \\
\hline $\mathbf{2}$ & Panchamirtham & Tiruchendur & $3.96 \times 10^{8}$ & 396 \\
\hline $\mathbf{3}$ & Panchamirtham & Pazhani & $0.57 \times 10^{8}$ & 57 \\
\hline
\end{tabular}

Table.1b Enumeration of total number of micro-organgisms

\begin{tabular}{|c|c|c|c|c|c|c|c|c|c|c|c|c|c|c|c|c|}
\hline \multirow{3}{*}{$\begin{array}{l}\text { S. } \\
\text { No }\end{array}$} & \multirow{3}{*}{ MEDIA } & \multicolumn{15}{|c|}{ OBSERVATION } \\
\hline & & $\mathbf{S}_{1}$ & $\mathbf{S}_{2}$ & $S_{3}$ & $\mathbf{S}_{1}$ & $\mathbf{S}_{2}$ & $\mathbf{S}_{3}$ & $\mathbf{S}_{1}$ & $\mathbf{S}_{2}$ & $S_{3}$ & $S_{1}$ & $\mathbf{S}_{2}$ & $S_{3}$ & $\mathbf{S}_{1}$ & $\mathbf{S}_{2}$ & $S_{3}$ \\
\hline & & \multicolumn{3}{|c|}{$10^{-2}$} & \multicolumn{3}{|c|}{$10^{-3}$} & \multicolumn{3}{|c|}{$10^{-4}$} & \multicolumn{3}{|c|}{$10^{-5}$} & \multicolumn{3}{|c|}{$10^{-6}$} \\
\hline 1. & EMB & 104 & 2 & 6 & 1 & - & 2 & - & - & 2 & - & - & - & - & - & - \\
\hline 2. & LB & 24 & 178 & 15 & 1 & 14 & 2 & - & 13 & 14 & - & 35 & 2 & - & 2 & 3 \\
\hline 3. & NA & 30 & $\infty$ & 1 & 5 & 5 & - & 7 & - & - & 1 & - & $\infty$ & - & - & 2 \\
\hline 4. & R2A & 53 & 11 & 5 & 1 & $\infty$ & 1 & 1 & 130 & 1 & 1 & 5 & - & 1 & - & - \\
\hline 5. & Endo & 104 & 1 & 1 & - & - & - & - & - & - & - & - & - & - & - & - \\
\hline
\end{tabular}

Sucrose tolerance based on sample brix 75 degree. Sucrose tolerance were tested at $5 \%$, 70\%, 75\% and 80\% was in MRS broth. Each condition was incubated under aerobic condition for twenty four hours. Then the bacterial growth was observed at $600 \mathrm{~nm}$ in a spectrophotometer (Make and Model).

\section{Acid production test}

Acid production test was carried out for the bacteria in L broth supplemented with one percent bromocresol blue as indicator. After twenty four hours incubation, the acid production test was ascertained through the change of colour from blue to yellow.

\section{Results and Discussion}

Enumeration, isolation and purified of LAB

Samples were selected at three different location (Thiruparankundram, Tiruchendur and Pazhani), resulted in isolation of 787 bacteria from five different media viz., EMB, LB, NA, R2A and Endo agar. The counts were observed for three days continuously upto $10^{-6}$ dilutions (Table 1a and $1 \mathrm{~b}$ ).

Eighty four isolates were randomly selected based on their colour, shape and size. All the isolates were purified by using four streak method to get pure single colony.

\section{Acid production}

Among the 84 bacterial isolates, seven isolates were found to be acid producer based on reaction of colour changes from blue colour medium to yellow colour. Following bacterial isolates such as M2S2B1, M2S3B5, M2S3B7, M4S2B1, M4S2B6, M4S2B7 and M4S3B1 were found to produce acid. These are the bacterial isolates that were able to tolerate the acidic condition due to the hydrocholoric acid secretion in our stomach.

\section{Screening for probiotic properties}

\section{pH and acid resistance}

Spontaneously fermented foods may constitute a reservoir for new LAB strains 
with potential probiotic characteristics. The LAB strains were screened for their ability to survive in the passage through the gastrointestinal tract (GIT), to adhere in epithelial surfaces and for their antagonistic activity towards pathogens. Figure 1 showed all the isolates grew in $\mathrm{pH} 3$. Fifty one percent of bacterial isolates exhibited maximum growth and $48 \%$ of the isolates showed minimum growth at $\mathrm{pH} 4$. Thirty three percent and $67 \%$ isolates exhibited maximum and minimum growth at $\mathrm{pH} 5$, respectively. Eighty two percent of bacterial isolates were able to grow in $\mathrm{pH} 8$ and minimum growth was observed only in $17 \%$ of the isolates. Panchamirtham is mainly made from jaggery, and it can constitute upto $75 \%$ of the final product. Sucrose is one of the major sugars present in jaggery, and its concentration ranges between 66-77\% (Chand et al., 2012). All the bacterial isolates tolerated $5 \%, 70 \%, 75 \%$ and $80 \%$ and showed (Fig. 2) remarkable tolerance towards sucrose content. Overall, seventeen isolates showed the highest sucrose tolerance. Remaining sixty seven isolates were observed the lowest growth. The decline in the viable cell counts might be due to $\mathrm{pH}$ diff erences between pretreatment ( $\mathrm{pH}$ 5.4) and fermentation medium, where the initial $\mathrm{pH}$ of cashew apple juice was 4.0. Previously, Mousavi et al., 2013 reported that the initial $\mathrm{pH}$ and nutrient differences potentially induced the stress on the microorganisms and thereby decreased the microbial growth at the early stage of fermentation (lag phase). At the end of fermentation process, population of lactic acid bacteria in expand custard apple juice remained at levels exceeding $6.00 \mathrm{log}$ $\mathrm{CFU} / \mathrm{mL}$ except in case of $L$. acidophilus which was less than $6 \log \mathrm{CFU} / \mathrm{mL}$ which is similar to the findings of Salmeron et al., (2014).

In conclusion, results clearly revealed that there was a high level of diversity in the LAB microflora from fermented fruit mix. Among the 84 bacterial isolates, seven isolates produced acid after $24 \mathrm{~h}$ of incubation. The study concluded that bacterial isolates can tolerate and survive hydrocholoric environment in stomach proving their capability as efficient LAB. There are no evidence about microbial diversity and their characterization from panchamirtham. Further investigations are studied for understanding the microflora which could be used to develop a fermentation process that is acceptable in concern with food hygiene.

\section{References}

Angchok, D., Dwivedi, S. K. and Ahmed, Z. 2009. Traditional foods and beverages of Ladakh. Indian Journal Traditional Knowledge. 8(4): 551-558.

Angmo, K., and Bhalla, T. C. 2014. Preparation of Phabs - an indigenous starter culture for production of traditional alcoholic beverage, Chhang, in Ladakh. Indian Journal of Traditional Knowledge. 13(2): 347-351.

Bosnea, L.A., Moschakis, T. Nigam, P.S. and Biliaderis, C.G. 2017. Growth adaptation of probiotics in biopolymerbased coacervate structures to enhance cell viability. LWT -Food Science and Technology. 77: 282-289.

Chand, K., Singh, A. and Kulshrestha, M. 2012. Jaggery quality effected by hilly climatic conditions. Indian Journal Traditional Knowledge. 11: 172-176.

Gagne-Bourque, M. Xu, F., Dumont, M.J. and Jabaji, S. 2016. Encapsulation of Lactobacillus casei ATCC 393 cells and evaluation of their survival after freezedrying, storage and under gastrointestinal conditions. Journal of Food Engineering. 168: 52-59.

Huang, Y. H., Lai, Y. J. and Chou, C.C. 2011. Fermentation temperature affects the antioxidant activity of the enzymeripened sufu, an oriental traditional 
fermented product of soybean. Journal of Bioscience and Bioengineering. 112: 49-53.

Mousavi, Z.E., Mousavi, S.M. Razavi, S.H. Hadinejad, M. Emam-Djomeh, Z. and Mirzapour, M. 2013. Eff ect of fermentation of pomegranate juice by Lactobacillus plantarum and Lactobacillus acidophilus on the antioxidant activity and metabolism of sugars, organic acids and phenolic compounds. Food Biotechnology. 27: $1-13$.

Salmeron, I., Thomas, K. and Pandiella, S.S. 2014. Eff ect of substrate composition and inoculum on the fermentation kinetics and flavour compound profiles of potentially non-dairy probiotic formulations. LWT-Food Science and Technology. 55, 240-247.
Schoina, V., Terpou, A. Angelika-Ioanna, G.A. Koutinas, A. Kanellaki, M. and Bosnea, L. 2014. Use of Pistacia terebinthus resin as immobilization support for Lactobacillus casei cells and application in selected dairy products. Journal of Food Science and Technology. 52(9): 5700-5708.

Terpou, A., Gialleli, A.I. Bekatorou, A. Dimitrellou, D. Ganatsios, V. Barouni, E. Koutinas, A.A. and Kanellaki, M. 2017. Sour milk production by wheat bran supported probiotic biocatalyst as starter culture. Food and Bioproducts Processing. 101: 184-192.

Yeung, E.W. Ng, M., and Tong, P.S. 2011. Effects of yogurt starter cultures on the survival of Lactobacillus acidophilus. International Journal of Food Microbiology. 145(1): 169-175.

\section{How to cite this article:}

Uma Maheshwari, S., S. Amutha, G. Hemalatha, N. Senthil, R. Anandham and Kumutha, K. 2018. Characterization of Probiotic Bacteria from Fermented Fruit Mix. Int.J.Curr.Microbiol.App.Sci. 7(02): 2236-2242. doi: https://doi.org/10.20546/ijcmas.2018.702.269 